\title{
Pengaruh Motivasi Kerja ,Kompetensi,Dan Kompensasi Terhadap Kinerja Karyawan Pada PT Finansia Multi Finance Cabang Kedoya
}

\author{
Muhammad Guruh \\ Dosen Fakultas Ekonomi Universitas Pamulang \\ Email : muhammad.guruh23@gmail.com
}

\begin{abstract}
ABSTRAK
Penulisan ini bertujuan untuk mengetahui fenomenal dan memperoleh bukti emperik, serta kesimpulan tentang pengaruh Motivasi kerja,kompetensi dan kompensasi terhadap kinerja karyawan pada PT Finansia Multi Finanace cabang Kedoya .

Metode dalam penelitian ini adalah penelitian kepustakaan dan penelitian lapangan dengan kuesioner. Sifat penelitian ini termasuk penelitian deskriptif kuantitatif yaitu penelitian yang memberikan gambaran atau deskripsi suatu data yang dilakukan dalam hal untuk mengetahui adanya hubungan antara variabel bebas dengan variabel terikat. Sedangkan untuk menguji hipotesis digunakan uji regresi berganda, uji korelasi berganda, uji koefisien determinasi, uji $\mathrm{T}$ dan uji F.Hasil pengujian hipotesis

Hasil penelitian terdapat pengaruh positif antar Motivasi kerja $\left(\mathrm{X}_{1}\right)$ memiliki koefisien regresi sebesar 0,368 ( besar koefisien regresi variabel Motivasi kerja $\left(\mathrm{X}_{1}\right)$ sebesara 36,8 ) trehadap kinerja kerja karyawan (Y) dan nilai $\mathrm{T}_{\text {hitung }}$ sebesar 2,247 dengana tingkat signifikasi 0,040 (<0,050 ). Hal ini berarti bahwa Motivasi kerja (X1) berpengaruh signifikan terhadap kinerja karyawan, terdapat pengaruh positif antar kompentensi (X2 )memiliki koefisien regresi sebesar 0,372 ( besar koefisien regresi variabel kompetensi (X2) sebesara 37,2 ) terhadap kinerja kerja karyawan (Y) dan nilai Thitung sebesar 2,214 dengana tingkat signifikasi 0,010 $(<0,050)$ .Hal ini berarti bahwa Kompetensi (X2) berpengaruh signifikan terhadap kinerja karyawan, terdapat pengaruh positif antar kompensasi (X3 )memiliki koefisien regresi sebesar 0,271 ( besar koefisien regresi variabel kompensasi (X3) sebesara 27,1 ) terhadap kinerja kerja karyawan (Y) dan nilai Thitung sebesar 2,028 dengana tingkat signifikasi 0,045 (<0,050). Hal ini berarti bahwa Kompensasi $\left(\mathrm{X}_{3}\right)$ berpengaruh signifikan terhadap kinerja karyawan .
\end{abstract}

\section{Kata Kunci: Motivasi kerja , Kompentensi, Kompensasi Dan Kinerja Karyawan.}




\section{PENDAHULUAN}

Bisnis saat ini di tuntut menciptakan kinerja karyawan yang tinggi untuk pengembangan perusahaan .perusahaan harus mampu membangun dan meningkatkan kinerja di dalam lingkunganya.keberhasilan

perusahaan tersebut de pengaruhi oleh factor ,salah satu factor penting adalah sumber daya manusia,karena sumber daya manusi merupakan pelaku dari seluruh tingkat perencanaan sampai dengan evaluasi yag mampu memanfaatkan sumberdaya -sumberdaya lainya yang dimilki oleh organisasi atau perusahaan

Keberadaan sumber daya manusia di dalam suatu perusahaan memegang peranan sangat penting.Tenaga kerja memiliki potensi yang besar untuk menjalankan aktivitas perusahaan .Potensi setiap sumber daya manusia yang ada dalam perusahaan harus dapat di manfaatkan dengan sebaikbaiknya sehingga mampu memberikan output optimal.

Dalam meningkatkan kinerja karyawannya perusahaan menempuh beberapa cara misalnya melalui pendidikan,pelatihan,pemberian kompensasi yang layak ,meciptakan lingkungan kerja yang kondusif dan pemberian motivasi .Melalui prosesproses tersebut ,karyawan di harapkan akan lebih memaksimalkan tanggung jawab atas pekerjaan mereka karena para karyawan telah terbekali oleh pendidikan dan pelatihan yang tentu berkaitan dengan implemetasi kerja mereka .Sedangkan pemberian kompensasi,lingkungan kerja yang baik serta pembrian motivasi pada dasarnya adalah hak para karyawan dan merupakan kewajiban dari pihak perusahaan untuk mendukung kontribusi para karyawan dalam rangka mencapai tujuan yang telah di tentukan .

Prestasi kerja karyawan bukan suatu kebetulan saja,tetapi factor yang mempengaruhi di antaranya pemberian kompensasi dan motivasi.Prestasi kerja akan dapat di capai jika di dahului dengan perbuatan yaitu melaksakan tugas yang di bebenakan .para karyawan akan lebih termotivasi untuk melakukan tugas dan tanggung jawab atas pekerjaan mereka apabilan perusahaan mengerti dan memperhatikan betul akan kebutuhan para karyawan yang pada dasarnya adalah mereka bekerja untuk mendapatkan uang, dalam hal ini berbentuk gaji.Setiap anggota dari suatu organisasi mempunya kepetingan dan tujuan sendiri ketikan bergabung pada organisasi tersebut.Bagi sebagian karyawan ,harapan untuk mendapatkan uang hanyalah satu dari banyak kebutuhan yang terpenuhi melalui kerja .Seorang yang bekerja akan merasa lebih di hargai oleh masyarakat di sekitarnya ,di bandingkan yang tidak bekerja.

\section{A. Tujuan Penelitian}

1. Untuk mengetahui seberapa besar pengaruh motivasi ( X1) kerja terhadap ( $\mathrm{Y}$ ) kinerja karyawan PT Finansia Multi Finance cabang Kedoya.

2. Untuk mengetahui seberapa besar pengaruh kompetensi ( $\mathrm{X}$ 2 ) karyawan terhadap ( $\mathrm{Y}$ ) kinerja karyawan PT Finansia Multi Finance cabang Kedoya.

3. Untuk mengetahui seberapa besar pengaruh kompensasi ( $\mathrm{X}$ 3 ) terhadap ( Y ) kinerja PT 
Finansia Multi Finance cabang Kedoya.

4. Untuk mengetahui seberapa besar pengaruh motivasi ( X1 ), kompetensi (X2), kompensasi ( X3 ) terhadap (Y) kinerja PT Finansia Multi Finance cabang Kedoya.

\section{B. Manfaat Penelitian}

Penelitian ini diharapkan dapat memberikan manfaat bagi pihak-pihak yangterkait:

1. Bagi PT Finansia Multi Finance cabang Kedoya

Sebagai masukan dan saran yang dapat digunakan dalam meningkatkan kinerja organisasi melalui motivasi kerja ,kompetensi, dan kompensasi seingga banyak karyawan yang meningkat Karirnya karena memiliki kinerja yang baik yang akhirnya membuat perusahaan makin berkembang dan besar .

2. Bagi Penulis

Sebagai media untuk mendapatkan pengalaman langsung dalam penelitian sehingga dapat menerapkan ilmu yang diperoleh dalam perkulihan pada keadaan yang sebenarnya di lapangan.

3. Bagi Akademisi

Sebagai bahan masukkan untuk penelitian lanjutan tentang masalah sumber daya manusia di masa mendatang.

\section{LANDASAN TEORI}

\section{A. Motivasi Kerja}

Manusia sebagai salah satu komponen dasar didalam organisasi publik harus memiliki motivasi yang tersimpan didalam hati atau keinginannya yang dapat memacu untuk meraih apa yang dicita-citakan. Motivasi adalah konsep yang menguraikan tentang kekuatan-kekuatan yang ada dalam diri karyawan yang memulai dan dapat mengarahkan perilaku orang tersebut (Gibson,Ivancevich dan Donneyly .2004:94).

\section{B. Kompetensi}

\section{Pengertian}

Konsep kompetensi mulai menjadi trend dan banyak dibicarakan dan saat ini menjadi sangat populer terutama dilingkungan perusahaan multinasional dan nasional yang "modern". Istilah dan konsep competency sebenarnya telah diperkenalkan seorang penulis manajemen Amerika Serikat dalam buku The Competence Manager. Dalam buku tersebut Boyatzis menyampaikan dalil bahwa manajer bisnis Amerika Serikat harus memiliki kompetensi tertentu bila bisnis dan ekonomi Amerika Serikat tidak ingin dikalahkan Jepang dan Eropa (Ruky. Achmad S., 2006:103).

\section{Faktor yang Mempengaruhi} Kompetensi

Organisasi berkembang pesat mengikuti perubahan yang cepat dan bersifat global. Sederap dengan dinamika perubahan tersebut pengkajian perlu dilakukan terus menerus. Pemimpin harus memiliki kompetensi yang diperlukan untuk secara kreatif mampu menyelesaikan berbagai permasalahan dan tantangan akibat perubahan yang cepat dan penuh ketidak pastian. 
(Soeharyo, S. dan Sofia, 2001:25). Adapun beberapa faktor yang mempengaruhi kompetensi (Wibowo, 2008: 102) adalah:

a. Keyakinan dan Nilai-nilai.

Keyakinan orang tentang dirinya maupun terhadap orang lain akan sangat mempengaruhi perilaku.

b. Ketrampilan.Ketrampilan memainkan peran di kebanyakan kompetensi. Pengembangan ketrampilan yang secara spesifik berkaitan dengan kompetensi dapat berdampak baik pada organisasi dan kompetensi individual.

c. Pengalaman. Keahlian dari banyak kompetensi memerlukan pengalaman mengorganisasi orang, komunikasi dihadapan kelompok, menyelesaikan masalah, dan sebagainya.

d. Karakteristik Kepribadian. Kepribadian dapat mempengaruhi keahlian manajer dan pekerja dalam sejumlah kompetensi, termasuk dalam menyelesaikan konflik, menunjukkan kepedulian interpersonal, kemampuan bekerja dalam tim, memberikan pengaruh dan membangun hubungan.

e. Motivasi.

Motivasi merupakan faktor dalam kompetensi yang dapat berubah, dengan memberikan dorongan, apresiasi terhadap pekerjaan bawahan, memberikan pengakuan dan perhatian individual dari atasan dapat mempunyai pengaruh positif terhadap motivasi seorang bawahan. Apabila manajer dapat mendorong motivasi pribadi seorang pekerja, kemudian meyelaraskan dengan kebutuhan bisnis, mereka akan sering menemukan peningkatan dalam sejumlah kompetensi yang mempengaruhi kinerja.

f. Isu Emosional. Hambatan emosional dapat membatasi penguasaan kompetensi.

g. Kemampuan Intelektual. Kompetensi tergantung pada pemikiran kognitif seperti pemikiran konseptual dan pemikiran analitis. Sudah tentu faktor seperti pengalaman dapat meningkatkan kecakapan dalam kompetensi ini.

h. Budaya organisasi. Budaya organisasi mempengaruhi kompetensi sumber daya manusia dalam kegiatan.

\section{Model Kompetensi}

Model model kompetensi menjelaskan perilku-perilaku yang terpenting yang diperlukan untuk kinerja unggul dalam posisi, Peran atau fungsi yang spesifik, yang bisa terdiri dari beberapa atau berbagai kompetensi. Model kompetensi dibedakan menurut kepentingannya, menjadi model kompetensi untuk Leadership, coordination, experts dan support. Model kompetensi untuk kepemimpinan dan koordinator pada dasarnya 
sama dan meliputi : komitmen pada pembelajaran berkelanjutan, orientasi pada pelayanan masyarakat, berpikir konseptual, pengambilan keputusan , mengembangkan orang lain, standar profesionalisme tinggi, dampak pada pengaruh dan inovasi, kepemimpinan kepedulian organisasi, orientasi pada kinerja, orientasi pada pelayanan, strategi bisnis, kerja sama tim dan keberagaman.

\section{Tipe kompetensi}

Tipe kompetensi yang berbeda dikaitkan dengan aspek perilaku manusia dan dengan kemampuannya mendemontrasikan kemampuan perilaku tersebut.

Ada beberapa tipe kompentensi yang dapat dijelaskan sebagai berikut:

a. Planning Competency, dikaitkan dengan tindakn tertentu seperti menetapkan tujuan, menilai risiko dan mengembangkan urutan tindakan untuk mencapai tujuan.

b. Influence competency, dikaitkan dengan tindakan seperti mempunyai dampak pada orang lain, memaksa melakukan tindakan tertentu atau membuat keputusan tertentu, dan member inspirasi untuk bekerja menuju tujuan organisasional.

c. Communication

competency, dalam bentuk kemampuan berbicara, mendengarkan orang lain, komunikasi tertulis dan noverbal.

d. Interpersonal competency, meliputi empati, membangun consensus, networking, persuasi, negosiasi, diplomasi, manajemen konflik, menghargai orang lain, dan menjadi tim player.

e. Thinking competency, berkenaan dengan berfikir strategis, berfikir analitis, berkomitmen terhadap tindakan, memerlukan kemampuan kognitif, mengidentifikasi mata rantai, dan membangkitkan gagasan kreatif.

f. Organizational competency, meliputi kemampuan merencanakan pekerjaan, mengorganisasi sumber daya, mendapatkan pekerjaan yang dilakukan, mengukur kemajuan dan mengambil risiko yang diperhitungkan.

g. Human resources management competency, merupakan kemampuan sumber daya manusia bidang team building, mendorong partisipasi, mengembangkan bakat , mengusahakan umpan balik kinerja.

h. Leadership competency, merupakan kompetensi yang meliputi kecakapan memposisikan diri, mengembangkan

organisasional, mengelola transisi, orientasi strategis, membangun visi, merencanakan masa depan, menguasai perubahan dan 
memelopori kesehatan tempat kerja.

i. Client service competency, merupakan kompetensi berupa mengidentifikasi dan menganalisis pelanggan, orientasi pelayanan dan pengiriman, bekerja dengan pelanggan. Membangun partnership dan berkomitmen terhadap kualitas

j. Business compentency, merupakan kompetensi yang meliputi manajemen financial, ketrampilan mengambil keputusan bisnis, bekerja dalam system, menggunakan ketajaman bisnis, membuat keputusan bisnis dan membangkitkan pendapatan.

k. Self management competency, kompetensi berkaitan dengan menjadi motivasi diri, bertindak dengan percaya diri, mengelola pembelajaran sendiri, mendemonstrasikan fleksibilitas dan berinisiatif.

1. Technical competency, kompetensi yang berkaitan dengan mengerjakan tugas kantor, bekerja dengan teknologi computer, menggunakan peralatan lain, mendemonstrasikan keahlian teknis dan professional, dan membiasakan bekerja dengan data dan angka.

\section{Kompensasi}

\section{Pengertian Kompensasi}

Pada dasarnya manusia bekerja juga ingin memperoleh uang untuk memenuhi kebutuhan

hidupnya. Untuk itulah seorang karyawan mulai menghargai kerja keras dan semakin menunjukkan loyalitas terhadap perusahaan dan karena itulah perusahaan memberikan penghargaan terhadap prestasi kerja karyawan yaitu dengan jalan memberikan kompensasi.

Salah satu rara
manajemen meningkatkan prestasi kerja, memotivasi dan meningkatkan kinerja para karyawan adalah melalui kompensasi (Malthis. Jackson. 2000). Kompensasi penting bagi karyawan sebagai individu karena besarnya kompensasi mencerminkan ukuran karya mereka diantara para karyawan itu sendiri, keluarga dan masyarakat( Hani. Handoko. 2003:114118). Kompensasi acapkali juga disebut penghargaan dan dapat didefinisikan sebagai setiap bentuk penghargaan yang diberikan kepada karyawan sebagai balas jasa atas kontribusi yang mereka berikan kepada organisasi (Panggabean. Mutiara.S. 2002). Selain itu, terdapat beberapa pengertian kompensasi dari beberapa tokoh yaitu(Malayu S.P Hasibuan.2003:246 ):

a. Kompensasi adalah apa yang seorang pekerja terima sebagai balasan dari pekerjaan yang 
diberikannya. Baik upah

per jam ataupun gaji periodik didesain dan dikelola oleh bagian personalia.

b. Kompensasi adalah segala sesuatu yang dikonstitusikan atau dianggap sebagai suatu balas jasa atau ekuivalen.

Pengertian kompensasi juga terdapat pada berbagai literatur yang dikemukakan oleh beberapa pakar, antara lain:

a. Kompensasi merupakan istilah luas yang berkaitan dengan imbalan imbalan finansial yang diterima oleh orang-orang melalui hubungan kepegawaian mereka dengan organisasi (Simamora. H. 2004:442)

b. Kompensasi karyawan adalah setiap bentuk pembayaran atau imbalan yang diberikan kepada karyawan dan timbul dari dipekerjakannya karyawan itu (Desler. 2006 :87).

c. Kompensasi adalah segala sesuatu yang diterima para karyawan sebagai balas jasa untuk kerja mereka (Hani. Handoko. 2003:120). Jadi melalui kompensasi karyawan dapat meningkatkan prestasi kerja, motivasi, kepuasan,kinerja serta dapat meningkatkan kebutuhan hidup mereka.

\section{Jenis-jenis kompensasi}

Kompensasi mempunyai tiga komponen sebagai berikut :

a. Pembayaran uang secara langsung (direct financial payment) dalam bentuk gaji, dan intensif atau bonus/komisi.

b. Pembayaran tidak langsung (indirect payment) dalam bentuk tunjangan dan asuransi.

c. Ganjaran non finansial (non financial rewards) seperti jam kerja yang luwes dan kantor yang bergengsi.

\section{Tujuan Manajemen Kompensasi}

Tujuan manajemen kompensasi adalah untuk membantu organisasi mencapai keberhasilan strategis sambil memastikan keadilan internal dan eksternal. Internal equity atau keadilan internal memastikan bahwa jabatan yang lebih menantang atau orang yang mempunyai kualifikasi lebih baik dalam organisasi dibayar lebih tinggi. Sementara itu, external equity atau keadilan eksternal menjamin bahwa pekerjaan mendapatkan kompensasi secara adil dalam perbandingan dengan pekerjaan yang sama di pasar tenaga kerjanya. Tujuan manajemen kompensasi adalah (Wibowo. 2010:350):
a. Memperoleh
Personel Berkualitas
b. Mempertahankan Karyawan yang Ada.
c. Memastikan Keadilan
d. Menghargai Perilaku yang Diinginkan
e. Mengawasi Biaya
f. Mematuhi Peraturan
g. Memfasilitasi
Saling 
h. Efisiensi Administratif Selanjutnya

4. Asas dan Tujuan Kompensasi Perusahaan harus menetapkan program-program kompensasi yang didasarkan atas asas keadilan serta asas kelayakan dan kewajaran, dengan memperhatikan undang-undang perburuhan yang berlaku. Berikut ini asasasas yang penting untuk diterapkan dalam pemberian kompensasi (Suwatno dan Priansa, Donni. 2011:220):

a. Asas Keadilan

b. Asas Kelayakan dan Kewajaran

5. Sistem Kompensasi

Sistem kompensasi ialah suatu sistem yang terdiri dari komponen-komponen

kompensasi dari mulai penentuan besaran kompensasi dan cara pemberiannya. Dan pada dasarnya tujuan sistem kompensasi (Suwatno dan Priansa, Donni. 2011:224) adalah:

a. Menghargai Prestasi Kerja

b. Menjamin Keadilan

c. Mempertahankan Kary

d. Memperoleh Karyawan yang Bermutu

e. Pengendalian Biaya

f. Memenuhi Peraturan yang Berlaku

6. Kriteria

Kompensasi

$\begin{array}{cr}\text { Kebijakan } & \text { tentang } \\ \text { pemberian } & \text { kompensasi }\end{array}$

Pemberian

terhadap karyawan bukan sesuatu yang statis, melainkan bersifat dinamis. Hal ini berarti ketentuan pemberian kompenasi suatu perusahaan dapat berubah dari waktu ke waktu. Faktor-faktor yang mempengaruhi ketentuan pemberian kompensasi antara lain: keadaan perekonomian suatu negara, kebijaksanaan pemerintah, tuntutan serikat pekerja, perkembangan ilmu pengetahuan dan teknologi. Namun demikian, agar perubahan ketentuan tersebut tidak begitu menimbulkan keguncangan, ada beberapa kriteria yang perlu diperhatikan dalam penentuan kebijakan pemberian kompensasi, (Suwatno dan Priansa, Donni. 2011:229), antara lain:

a. Biaya Hidup

b. Produktivitas Kerja Karyawan

c. Skala Upah atau Gaji yang Berlaku

d. Kemampuan Membayar

e. Upah atau Gaji Sebagai Alat untuk Menarik, Mempertahankan, dan Memberikan Motivasi kepada Karyawan

f. Penawaran dan Permintaan Tenaga Kerja

g. Serikat Buruh atau Organisasi Karyawan

h. Posisi Jabatan Karyawan

i. Pendidikan dan Pengalaman Kerja

\section{Sistem Imbalan yang Efektif}

$$
\text { Dalam }
$$

usaha mengembangkan suatu sistem imbalan, para spesialis di bidang manajemen sumber daya manusia perlu melakukan empat hal (Siagian, Sondang, P. 2008:257):

a. Melakukan analisis pekerjaan. Artinya perlu 
disusun deskripsi jabatan, uraian pekerjaan dan standar pekerjaan yang terdapat dalam suatu organisasi.

b. Melakukan penilaian pekerjaan dikaitkan dengan keadilan internal. Dalam melakukan penilaian pekerjaan diusahakan tersusunnya urutan peringkat pekerjaan, penentuan nilai untuk setiap pekerjaan, susunan perbandingan dengan pekerjaan lain dalam organisasi dan pemberian point untuk setiap pekerjaan.

c. Melakukan survei berbagai sistem imbalan yang berlaku guna memperoleh bahan yang berkaitan dengan keadilan eksternal. Organisasi yang disurvai dapat berupa instansi pemerintah yang secara fungsional berwenang mengurus ketenagakerjaan, kamar dagang dan industri, organisasi profesi,serikat pekerja, organisasiorganisasi pemakai tenaga kerja lain dan perusahaan konsultant, terutama yang mengkhususkan diri dalam manajemen sumber daya manusia.

d. Menentukan harga setiap pekerjaan dihubungkan dengan harga pekerjaan sejenis di tempat lain. Dalam mengambil langkah ini dilakukan perbandingan antara nilai berbagai pekerjaan dalam organisasi dengan nilai yang berlaku di pasaran kerja.

\section{Kinerja}

Kinerja memiliki pengertian yang beragam dari berbagai pakar, tetapi tetap memiliki kesamaan secara umum. Kinerja adalah tingkat pencapaian hasil atas pelaksanaan tugas tertentu. Kinerja perusahaan adalah tingkat pencapaian hasil dalam rangka mewujudkan tujuan perusahaan(Simanjuntak, P., 2005:98). Informasi tentang kinerja organisasi merupakan suatu hal yang sangat penting digunakan untuk mengevaluasi apakah proses kinerja yang dilakukan organisasi selama ini sudah sejalan dengan tujuan yang diharapkan atau belum. Akan tetapi dalam kenyataannya banyak organisasi yang justru kurang atau bahkan tidak jarang ada yang mempunyai informasi tentang kinerja dalam organisasinya. Kinerja sebagai hasil-hasil fungsi pekerjaan/kegiatan seseorang atau kelompok dalam suatu organisai yang dipengaruhi oleh berbagai faktor untuk mencapai tujuan organisasi dalam periode waktu tertentu (Tika, P., 2006.) Performance atau Kinerja adalah hasil kerja yang dapat dicapai oleh seseorang atau kelompok orang dalam suatu organisasi sesuai dengan wewenang dan tanggungjawabnya masingmasing dalam upaya pencapaian tujuan organisasi (Mangkuprawia, S., 2009:220). 


\section{METODOLOGI PENELITIAN}

\section{Tempat dan waktu Penelitian}

Penulis dalam penyusunaan penelitian ini,mengadakan penelitian pada PT Finansia Multi Finance cabang Kedoya di Jakarta barat yaitu sebuah perusahaan yang bergerak di bidang pembiayaan motor .

a. Tempat penelitian

Penelitian di lakukan di

PT FinansiaMulti Finance cabang Kedoya yang beralamat di JL Arteri Kedoya NO 88 A88 B Kedoya Selatan Kebon Jeruk Jakarta barat .

b. Waktu Penelitian

Penelitian di lakukan selama 3 ( tiga ) bulan terhitung dari bulan januari 2017 sampai dengan maret 2017, tealah di laksanakan penelitian secra bertahap di awlai dengan melakukan survey (pendahuluaan ),yang di lakukan selanjutnya proposal penelitian,penaguna surat izin penelitian,pembuatan

instrument penelitian, konsultasi, penyebaran instrument kepada obyek penelitiaan ,pengolahan data dan penyusunan penelitian.

\section{Metode penelitian}

Metode penelitian menurut Sugiono (2007:15) di definisikan sebagai suatu cara ilmiah untuk mendapatkan data dengan tujuan dan kegunaan tertentu. Cara ilmiah berarti kegiatan penelitian tersebut di dasrakan pada cirri-ciri keilmuan yaitu. Rasional,empiris,dan sistematis.

\section{HASIL PENELITIAN}

\section{A. Kesimpulan}

1. Terdapat pengaruh positif antar Motivasi kerja ( $\mathrm{X}_{1}$ )memiliki koefisien regresi sebesar 0,368 ( besar koefisien regresi variabel Motivasi kerja ( $\mathrm{X}_{1}$ sebesara 36,8 ) trehadap kinerja kerja karyawan (Y) dan nilai $\mathrm{T}$ sebesar 2,247 dengan tingkat signifikasi $0,040(<0,050)$.Hal ini berarti bahwa Motivasi kerja $\left(\mathrm{X}_{1}\right)$ berpengaruh signifikan terhadap kinerja karyawan .

2. Terdapat pengaruh positif antar kompentensi $\left(\mathrm{X}_{2} \quad\right)$ memiliki koefisien regresi sebesar 0,372 ( besar koefisien regresi variabel kompetensi $\left(\mathrm{X}_{2}\right)$ sebesara 37,2) terhadap kinerja kerja karyawan (Y) dan nilai $\mathrm{T}$ sebesar 2,214 dengana tingkat signifikasi $0,010(<0,050)$.Hal ini berarti bahwa Kompetensi $\left(\mathrm{X}_{2}\right)$ berpengaruh signifikan terhadap kinerja karyawan

3. Terdapat pengaruh positif antar kompensasi $\left(\mathrm{X}_{3} \quad\right)$ memiliki koefisien regresi sebesar 0,271 ( besar koefisien regresi variabel kompensasi $\left(\mathrm{X}_{3}\right)$ sebesara 27,1 ) terhadap kinerja kerja karyawan (Y) dan nilai $\mathrm{T}$ sebesar 2,028 dengana tingkat signifikasi $0,045(<0,050)$. Hal ini berarti bahwa Kompensasi $\left(\mathrm{X}_{3}\right)$ berpengaruh signifikan terhadap kinerja karyawan.

4. Secara simultan semua variabel bebas berpengaruh signifikan terhadap variabel terikat dengan nilai sig. $0,000<\alpha \quad 0,05$. Pengaruh yang diberikan ketiga variabel bebas tersebut bersifat positif artinya semakin tinggi motivasi kerja, kompetensi dan 
kompensasi

maka mengakibatkan semakin tinggi pula kinerja karyawan yang dihasilkan.

\section{B. Saran}

Berdasarkan kesimpulan di atas dan hasil penelitian maka penulis memberikan saran , di harapan dapat bermanfaat bagi PT Finansia Multi Finance cabang Kedoya adapun saran tersebut sebagai berikut :

1. Perbaikan tingkat pengasilan yang di terima karywan setiap bulan harus di perhatikan dalam hal gaji yang di terima setiap bulan belum cukup untuk kebutuhan dasar rumah tangga,

2. Pembagian tugas yang jelas sehingga bisa lebih efektif dalam mencapai kinerja,dan kordinasi antar divisi sehingga memudahkan dalam menjalankan tugas masingmasing .

3. Lebih menjelaskan kepada karyawan agar Memahamii tugas dan fungsi dari setiap divisi dengan baik serta memahami aturan kerja yang sesuai dengan SOP yang ada,

4. Sosialisasi kebijakan yang baru dengan cepat dan jelas serta ada kesesuaian penghasilan dengan tugas dan fungsi dari karyawan hal ini bisa di perbaiki kedepan oleh pihak Manajemen perusahaan sehingga hal ini bisa membuat kinerja meningkat.

5. Perlu di perhatikan lagi oleh perusahaan apakah kompentensi karyawan yang ada sudah tepat dalam posisinya

\section{DAFTAR PUSTAKA}

Dessler, Gary, 2006. Manajemen Sumber Daya Manusia. Edisi ke sepuluh.PT Intan sejati.Klaten.

Echols, J. dan Shadily, Hasan, 1996.Kamus Bahasa Inggris Indonesia. PT Gramedia, Jakarta.

Ghozali, Imam, 2005. Aplikasi Analisis Multivariate dengan program SPSS.

Gibson, Ivancevich, dan Donnely, 2004. Organisasi. PT Erlangga, Jakarta.

Gordon, Anderson, 1992. Managing Performance

Appraisal System.Uk. Strathclyde Bisnis School

Hasibuan, Malayu, 2007. Organisasi dan Motivasi. PT. Bumi Aksara, Jakarta

Husein, Umar, 2002. Metode Riset Bisnis. PT. Gramedia Pustaka Utama, Jakarta

Indonesia, Gina Gania, 2006. Perilaku dan Manajemen Organisasi. Erlangga, Jakarta.

Ivancevich, J. M. Konopaske R. dan Matteson M.T., 2005. Organizational Behavior and Management. Seventh Edition.The McGraw-Hill Companies. Edisi Bahasa

Kennaa, E. and Beach, N., 2002. The essense of Human Resource Management. Penerbit Budi, Yogyakarta.

Malthias, R. L. dan Jakson, 2002.Manajemen Sumber Daya Manusia. Jakarta.

Mangkuprawira, Sjafri, 2009. Bisnis, manajemen, dan Sumberdaya Manusia. PT. Gramedia, Jakarta. 
Manulang, M., 1994.Manajemen Personalia.Ghalia Indonesia. Jakarta.

Notoatmodjo, Soekidjo, 2009. Pengembangan Sumber Daya Manusia. PT Rineka Cipta, Jakarta

PT Finansia Multi Finance , 2016. Peraturan Karyawan PT Finansia Multi Finance .Jakarta Rampesad, Hubert, K., 2006. Pertajam Kompetensi Anda dengan Personal Balance Scorecard. Sinergikan Ambisi Pribadi dengan Ambisi Perusahaan Anda. Edisi Indonesia.PPM, Jakarta.

Robbins, S. P., dan Judge, Timothy A., 2008. Perilaku Organisasi Edisi keduabelas Salemba Empat, Jakarta.

Ruky, Achmad, 2006. Sumber Daya Manusia Berkualitas mengubah Visi menjadi Realitas. PT. Gramedia Pustaka Utama, Jakarta

Schuler, R. S. J.,1999. Strategic Human Resource Management.Mass. Blackwell Publishers, USA.

Siagian, S. P., 2004. Manajemen Internasional. PT Bumi Aksara, Jakarta.
Simanjuntak, P., 2005. Manajemen dan Evaluasi Kinerja.Lembaga penerbit FE UI, Jakarta

Soeharyo, S. dan Sopiah, 2008.Perilaku Organisasional. Penerbit Andi, Yogyakarta.

Stoner.J. A. F dan Edward Freeman $R$., $\quad$ 2003.Manajemen.PT Prenhallindo, Jakarta.

Supranto, J., 2001. Statistik: Teori Dan Aplikasi. Edisi keenam. Erlangga, Jakarta.

Tika, P., 2006. Budaya Organisasi Dan Peningkatan Kinerja Perusahaan. PT Bumi Aksara, Jakarta

Veithzal, Rivai, 2008. Performance Appraisal: Sistem Yang Tepat Untuk Menilai

Veithzal, Rivai, dan Ella, Jauvani, 2009. Manajemen Sumber Daya manusia untuk Perusahaan.PT RAJAGRAFINDO PERSADA, Jakarta.

Wibowo, 2008.Manajemen Kinerja. PT grafindo Persada. Jakarta.

Yukl, Gary, 2006. Leadership in Organizations.Edisi ketujuh, Universitas at Albany State University of New York. 